\title{
WIESŁAW ŚMIGIEL \\ Wizyta duszpasterska, zwana kolędą, jako szansa na ewangelizację osób dystansujących się od Kościoła
}

W Polsce wzrasta liczba chrześcijan, którzy przez chrzest formalnie stali się członkami Kościoła, ale w praktyce żyją z dala od wspólnoty eklezjalnej ${ }^{1}$. Towarzyszy temu często zanegowanie lub selektywne przyjmowanie prawd wiary, kryzys sumienia i relatywizm moralny ${ }^{2}$. Dlatego ważnym zadaniem duszpasterstwa jest troska o dystansujących się od Kościoła, aby doprowadzić do ich nawrócenia (por. EE 47). Wpisuje się to również w zadanie nowej ewangelizacji, która jest skierowana do tych, którzy zagubili, zneutralizowali lub

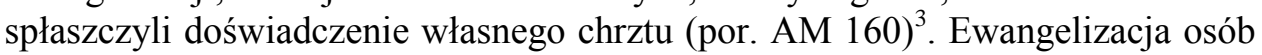
dystansujących się od Kościoła zakłada poszukiwanie nowych form aktywności pastoralnej oraz rewizję tradycyjnego duszpasterstwa ${ }^{4}$.

Wiesław Ś M I G I E L, bp dr hab. prof. KUL, kierownik Katedry Teologii Pastoralnej Szczegółowej KUL, Lublin-Pelplin, e-mail: smigiel@kul.pl

${ }^{1} \mathrm{~W}$ Polsce zjawisko to z roku na rok jest coraz bardziej widoczne, choć nadal jego zakres jest znacznie mniejszy niż na Zachodzie Europy. Jednak jeśli zachowają się współczesne trendy w przemianach religijności, to również w Polsce będzie to jeden z głównych problemów duszpasterskich. Zob. Konferencja Episkopatu Polski: Niewierzacy w parafii - wstępne wytyczne duszpasterstwa. „Koszalińsko-Kołobrzeskie Wiadomości Diecezjalne”. R. 16: 1988 nr 5- 6 s. 140-148; Komitet ds. Dialogu z Niewierzącymi Konferencji Episkopatu Polski: Niewierzacy w parafii sugestie duszpasterskie. „Akta Konferencji Episkopatu Polski”. R. 1999 nr 3 s. 59-65.

${ }^{2}$ Zob. E. S a k o w i c z: Katolicy dystansujacy się od Kościoła. W: Leksykon teologii pastoralnej. Red. R. K a m iń s k i, W. Pr z y g o d a, M. F i a łk o w s k i. Lublin 2006 s. 363-366.

${ }^{3}$ Por. Kongregacja Nauki Wiary: Nota doktrynalna na temat pewnych aspektów ewangelizacji (3 XII 2007). „L'Osservatore Romano”. R. 29: 2008 nr 2 s. 54; G. R y ś: Jezusowa nowa ewangelizacja. W: Nowa ewangelizacja. Kerygmatyczny impuls w Kościele. Red. P. S o w a, K. K a p r o ń. Gubin (Wydawnictwo Przystanek Jezus) 2012 s. 13.

${ }^{4}$ Por. J-L. M o e n s. Na czym polega nowa ewangelizacja? W: Nowa ewangelizacja..., s. 21. 
Błędem byłoby skupienie się na tworzeniu i rozwijaniu nowych form duszpasterstwa, a lekceważenie tego, co jest stare i sprawdzone. Z duszpasterstwa należy eliminować tylko te praktyki, które nie są poprawne teologicznie i nie pomagają w doprowadzeniu człowieka do spotkania z Bogiem. Wprawdzie niektóre formy i metody ulegają dezaktualizacji ze względu na zmieniający się kontekst społeczno-kulturowy oraz towarzyszące temu przemiany religijności, jednak większość z nich wymaga odnowy, aby wciąż być skutecznym narzędziem ewangelizacji.

Wśród sprawdzonych form duszpasterstwa w Polsce, które są szansą na ewangelizację osób dystansujących się od Kościoła, jest wizyta duszpasterska, popularnie zwana kolędą ${ }^{5}$. Jest to zwyczaj odwiedzania przez duchownych swoich parafian w ich domach w okresie Bożego Narodzenia. W czasie kolędy duszpasterz spotyka się przede wszystkim z wierzącymi i praktykującymi, bo to oni zapraszają do swoich domów i mieszkań. Jednak zdarza się, że otwierają drzwi również dystansujący się od Kościoła, aby przeprowadzić rozmowę lub z przywiązania do tradycji. Postępując $\mathrm{w}$ zgodzie $\mathrm{z}$ założeniami nowej ewangelizacji takich ludzi nie wolno omijać, a raczej należy uznać, że to okazja do wzbudzenia lub wzmocnienia ich wiary.

\section{Zjawisko dystansowania się od Kościoła}

Problem katolików, którzy dystansują się lub są luźno związani z Kościołem staje się coraz bardziej aktualny. Wzrasta liczba chrześcijan, którzy przez chrzest formalnie stali się członkami Kościoła, ale w praktyce żyją z dala od wspólnoty eklezjalnej. Taka postawa ma wiele przyczyn. Zapewne erozja wiary łączy się z ogólnym laickim klimatem, któremu towarzyszy sekularyzm. Wielu wskazuje na postawę duchownych, którzy przez swoje nieewangeliczne działania zniechęcają do Kościoła, inni wskazują nadto na niekomunikatywny przekaz prawd wiary oraz brak komunikacji w Kościele. Katolicy świeccy nie zawsze rozumieją decyzje hierarchii, co powoduje wyobcowanie i uprzedzenia ${ }^{6}$. Zapewne spore znaczenie posiada również sytuacja egzystencjalna. Człowiek uwikłany w grzech ucieka od Kościoła, aby w ten sposób zrelatywizować sumienie. Niebagatelne znaczenie posiada również ogólny klimat społeczny i moda, która dla wielu ludzi jest wyznacznikiem kierunków myślenia i wartościowania. Niestety współczesność minimalizuje znaczenie religijności w życiu człowieka,

\footnotetext{
${ }^{5}$ Nazwa pochodzi od łac. calendae - pierwszy dzień miesiąca. Tak nazywano pieśni religijne śpiewane w okresie Bożego Narodzenia oraz upominki ofiarowane z okazji świąt lub podarki otrzymywane z racji śpiewania kolęd. Zob. P. J a n o w s k i: Kolęda, wizyta duszpasterska. Historia. W: EK T. IX Lublin: TN KUL 2002 kol. 348-349.

${ }^{6}$ E. S a k o w i c z: Katolicy dystansujący się od Kościoła, dz. cyt., s. 364.
} 
a także marginalizuje lub $\mathrm{w}$ skrajnych przypadkach neguje potrzebę kontaktu z Kościołem jako instytucją.

Analizując sytuację panującą w Europie papież Jan Paweł II napisał w posynodalnej adhortacji apostolskiej Ecclesia in Europa, że wszędzie zachodzi potrzeba nowego gloszenia Ewangelii - również tym, którzy sa już ochrzczeni. Wielu wspótczesnych Europejczyków sądzi, że wie, co to jest chrześcijaństwo, ale w rzeczywistości go nie zna. Często nawet podstawy i najbardziej zasadnicze pojęcia chrześcijaństwa nie sa znane. Wielu ochrzczonych żyje tak, jakby Chrystus nie istniat; powtarza się gest y $i$ znaki zwiazane $z$ wiara, zwłaszcza $w$ praktykach religijnych, ale nie odpowiada im rzeczywista akceptacja treści wiary $i$ przylgnięcie do Osoby Jezusa (EE 47). Towarzyszy temu często zanegowanie lub selektywne przyjmowanie prawd wiary ${ }^{7}$. Niejednokrotnie wiąże się to $\mathrm{z}$ kryzysem sumienia i relatywizmem moralnym. $\mathrm{Z}$ tych powodów dziś palącą potrzebą jest, nie tyle ochrzcić nowo nawróconych, ile doprowadzić do głębokiej przemiany już ochrzczonych (EE 47).

Zjawisko dystansowania się od Kościoła ochrzczonych jest charakterrystyczne przede wszystkim dla krajów europejskich, ale współcześnie powoli zaczyna dotykać Kościoła powszechnego. Polska nie jest wolna od tych zjawisk, choć zapewne postępują one nieco wolniej. Niektórzy autorzy wskazują na tzw. sekularyzację petzająca, która jest również niebezpieczna, ponieważ łatwo ją zlekceważyć, a w dalszej perspektywie degraduje religijność człowieka i osłabia jego łączność z Kościołem.

Katolicy dystansujący się od Kościoła, to ci, którzy z własnej woli oddalili się od życia Kościoła w wymiarze doktryny, moralności oraz praktyk religijnych $^{8}$. W praktyce najczęściej erozji uległa ich więź ze wspólnotą eklezjalną i jej instytucjami. Popularnie mówi się o takich katolikach, że są ustosunkowani do Kościoła $\mathrm{z}$ rezerwą, a wiarę zredukowali do elementu intelektualnego, zaniedbując jej praktyczny wymiar'. Ich sztandarowymi hasłami stały się stwierdzenia: ,jestem wierzący, ale niepraktykujący” lub „Chrystus tak, ale Kościół - nie". Cześć z nich utożsamia się z hasłem zdobywającym coraz większą popularność: wierzyć bez przynależności (believing without belonging) ${ }^{10}$.

\footnotetext{
${ }^{7}$ Por. R. K a m i ń s k i: Działalność zbawcza Kościoła w teorii i praktyce pastoralnej. Lublin (Wydawnictwo KUL) 2007 s. 216.

${ }^{8}$ Niektórzy autorzy wskazują na ciekawe zjawisko ,praktykujących, ale nie wierzących”. Pojawia się ono w krajach o trwałej religijności ludowej i silnym przywiązaniu do tradycji (np. Polska). Ludzie nie odczuwają więzi z Kościołem, ale praktykują uznając to za formę kultywowania tradycji. Czasem powodem takich postaw jest konformizm społeczny. Nie bez znaczenia pozostaje fakt braku sensownego świeckiego modelu przeżywania świąt i ważnych wydarzeń w życiu człowieka. Zob. E. S a k o w i c z: Praktykujacy a nie wierzacy. „Homo Dei”. R. 70: 2000 nr 4 s. 35-40.

${ }^{9}$ E. S a k o w i c z: Katolicy dystansujacy się od Kościoła, dz. cyt., s. 363.

${ }^{10}$ Postawa taka jest owocem $\mathrm{z}$ jednej strony sekularyzacji świata, a $\mathrm{z}$ drugiej poszukiwaniem sacrum. Najczęściej towarzyszą jej: pluralizm międzyreligijny, marginalizacja instytucji Kościoła
} 
Katolicy dystansujący się dobrowolnie, wskutek własnych przemyśleń lub doświadczeń egzystencjalnych, wybrali rodzaj „emigracji wewnętrznej” w Kościele. Niektórzy z nich, mimo formalnej przynależności do wspólnoty wierzących, realnie stają się jej wrogami.

Proces odchodzenia od Kościoła najwyraźniej jest widoczny na poziomie życia parafialnego. Katolicy zdystansowani najczęściej przyjmują tylko zewnętrzne warunki przynależności do wspólnoty kościelnej, a więc chrzest i zamieszkanie na terytorium parafii. Jednak w praktyce wielu ludzi ochrzczonych, szczególnie w krajach zlaicyzowanych, nie posiada świadomości przynależności do parafii ${ }^{11}$. Odrębnym zagadnieniem jest kryzys tradycyjnie rozumianej parafii, który w okresie posoborowym jest widoczny w Kościołach Europy Zachodniej ${ }^{12}$.

Wśród dystansujących się od Kościoła spotkać można oprócz osób obojętnych, również osoby o nastawieniu antyklerykalnym, czy wprost wrogie wobec Kościoła. Często postawa ta generowana jest przez określone środowiska polityczne, które wykorzystując niektóre środki społecznego przekazu, atakują i ośmieszają Kościół i duchowieństwo. Niestety nieliczna grupa katolików świeckich potrafi krytycznie i obiektywnie oceniać procesy zachodzące w Kościele. Większość opiera się na modzie i stereotypach. Trzeba z ubolewaniem przyznać, że za taką sytuację odpowiedzialni są w jakiejś mierze duchowni, którzy przez wieki uważali, że świeccy powinni praktykować, słuchać i wykonywać polecenia, a nie prowadzić dialog i być gotowym do krytycznego myślenia ${ }^{13}$. Niekiedy dystansowanie się od Kościoła może prowadzić do konwersji, do wstapienia do innego Kościoła chrześcijańskiego, a czasem modnej ostatnio apostazji1 ${ }^{14}$.

oraz indywidualizmu. A. N a p i ó r k o w s k i: Reforma i rozwój Kościoła. Duch Boży i instytucja. Kraków 2012 s. 160.

11 Takich parafian nazywa się ,parafianami odłączonymi” (G. L e B ra s), „parafianami śpiącymi” (J. H. F i c h t e r) lub „parafianami nominalnymi” (E. P i n). Do katolików dystansujących się od Kościoła należy zaliczyć również tych, którzy zachowali wiarę w istnienie Boga $\mathrm{i}$ przyjmują ogólne wartości głoszone przez Kościół, ale nie ma to odzwierciedlenia w ich postawach życiowych. Często określa się ich parafianami marginalnymi (J. H. F i c h t e r). Kryterium stosunku do praktyk religijnych wyznacza następujące grupy zdystansowanych od Kościoła.: praktykujących niesystematycznie, praktykujących rzadko (konformiści sezonowi - G. Le B ras) oraz niepraktykujących. E. S a k o w i c z: Katolicy dystansujący się od Kościoła, dz. cyt., s. 363-364.

${ }^{12}$ Por. W. P i w o w a r s k i: Socjologia religii. Lublin 2000 s. 123-137.

${ }^{13}$ Każde niebezpieczne zjawisko w duszpasterstwie powinno być wyzwaniem do szukania nowych i bardziej skutecznych rozwiązań. Dla przykładu można wskazać na problem rezygnowania z lekcji religii przez młodzież. Najczęściej dzieje się to po przyjęciu sakramentu bierzmowania, który przecież powinien być umocnieniem wiary i wezwaniem do świadectwa. W takich sytuacjach duszpasterze i katecheci nie powinni skupiać się na szukania sposobów ukarania takiej młodzieży, ale zadać sobie pytanie: co zrobić, aby takiej sytuacji zaradzić i jak zainteresować ich lekcjami religii?

${ }^{14}$ E. S a k o w i c z: Katolicy dystansujący się od Kościoła, dz. cyt., s. 364. 


\section{Spotkanie z dystansującymi się od Kościoła w czasie wizyty duszpasterskiej}

Kolęda to przede wszystkim okazja do spotkania z wierzącymi i praktykującymi katolikami. Raz w roku duszpasterz oficjalnie udaje się do ich domu, aby wspólnie się modlić, udzielić błogosławieństwa, nawiązać bliskie kontakty i dobrym słowem umocnić Kościół domowy. Wpisuje się również w realizację zaleceń Kodeksu Prawa Kanonicznego, który stwierdza, że proboszcz „pragnąc dobrze wypełnić funkcję pasterza, powinien starać się poznać wiernych powierzonych jego pieczy. Winien, zatem nawiedzać rodziny, uczestnicząc $\mathrm{w}$ troskach wiernych, zwłaszcza w niepokojach i smutku, oraz umacniając ich w Panu, jak również, jeśli w czymś nie domagają, roztropnie ich korygując" (kan. 529 §1). W czasie kolędy duszpasterz powinien przede wszystkim odwiedzić chorych, samotnych i ubogich, aby uczestniczyć w ich troskach i wspierać w trudach. Natomiast małżonkom i rodzinom pomagać $\mathrm{w}$ wypełnianiu ich powołania. Jest ona okazją do omówienia z parafianami ich problemów oraz nawiązania z nimi głębszych kontaktów ${ }^{15}$. Prowadzi to do pogłębienia więzi Kościoła domowego z Kościołem lokalnym w diecezji i parafii ${ }^{16}$. Można przyjąć tezę, że przyjęcie wizyty duszpasterskiej jest aktem publicznego wyznania wiary, a zarazem czynnikiem budującym wspólnotę parafialną ${ }^{17}$.

Współcześnie kolęda jest też okazją do nowej ewangelizacji, czyli głoszenia Dobrej Nowiny tym, którzy się pogubili. Trudno w czasie wizyty duszpasterskiej dotrzeć do tych, którzy oddalili się od Kościoła (zob. EN 54; RMi 33), zaniechali praktyk religijnych (AM 160) oraz żyją tak, jakby Chrystus nie istniał (EE 46) ${ }^{18}$. Ponieważ zasadniczo takie osoby nie przyjmują kolędy, choć sporadycznie można odnotować takie przypadki. Jednak nowa ewangelizacja jest skierowany również do tych, którzy nie porzucili niektórych praktyk religijnych, ale nie akceptują pełni treści wiary, utracili „zmysł wiary” i nie są już w stanie przylgnąć do Jezusa Chrystusa (EE 46). Do tej grupy należy spora część naszych parafian ${ }^{19}$. Niektórzy przyjmują duszpasterza w czasie kolędy, chociażby z przywiązania do tradycji lub w mniejszych środowiskach ze względu na presje społeczną. Ten ostatni czynnika ma coraz mniejsze znaczenie.

\footnotetext{
${ }^{15}$ Por. R. K a m i ń s k i: Parafia miejscem realizacji duszpasterstwa. W: Teologia pastoralna. Red. T e n ż e. T. 2. Teologia pastoralna szczegółowa. Lublin 2002 s. 73-75.

${ }^{16} \mathrm{Z}$. Ż y ź n i e w s ki: Kolęda, wizyta duszpasterska. Praktyka wspótczesna. W: Encyklopedia katolicka. T. 9. Lublin2002 kol. 349-350.

${ }^{17}$ Tamże, kol. 350.

${ }^{18}$ Zob. W. Pr z y c z y n a: Ewangelizacja. W: Leksykon teologii pastoralnej. Rad. R. K a m iń s ki, W. Pr z y g od a, M. F i ałk o w s k i. Lublin 2006 s. 254-257.

${ }^{19}$ Stąd propozycja Komisji Duszpasterstwa KEP, aby program duszpasterski w Polsce na lata 2013-2017 zbudować wokół tematu: Przez Chrystusa, z Chrystusem, w Chrystusie. Przez wiare $i$ chrzest do świadectwa. Pierwszy rok programu (2013-2014) skupia się na wierze w Syna Bożego i obejmuje głoszenie kerygmatu.
} 
Puntem wyjścia do dalszych rozważań jest przypomnienie, że w czasie kolędy duszpasterz jest gościem, a nie gospodarzami. To jest szczególne ważne w domach osób dystansujących się od Kościoła, gdyż z założenia duchowny nie posiada $w$ ich oczach autorytetu urzędowego, a jedynie swoją postawą może zapracować na autorytet osobisty. Zatem wszelkie przejawy arogancji lub zarozumiałości duchownego w punkcie wyjścia przekreślają możliwość skutecznej ewangelizacji ${ }^{20}$.

Jeśli osoby luźno związane z Kościołem przyjmują duszpasterza w czasie kolędy to jest to powód do radości i okazja do nowej ewangelizacji. Zawsze jednak należy dyskretnie rozeznać jaki jest tego powód. Czy jest to chęć spotkania i rozmowy z duchownym, aby wyjaśnić problemy dotyczące wiary? Może wyraz kultury i szacunku dla wartości, które reprezentuje Kościół? A może jest to interesowne, gdyż potrzeba jakiegoś zaświadczenia? Powód jest o tyle ważny, że wyznacza kierunek rozmowy, ale nawet jeśli nie jest szlachetny, to w żadnej mierze nie przekreśla wartości kolędy.

Praktyka kolędowa w Polsce nie sprzyja długim rozmową, szczególnie w dużych miastach, kiedy jednego dnia trzeba odwiedzić w dość krótkim czasie kilkanaście lub nawet kilkadziesiąt mieszkań. Nawet w tak trudnej sytuacji duszpasterz może zainicjować dialog, który w późniejszym czasie znajdzie swoją kontynuację.

W obecnym laickim klimacie można w czasie kolędy doświadczyć brutalnego ataku na Kościół, który najczęściej wyraża się w zarzutach wobec duchownych. Trzeba zrozumieć, że niestety antyklerykalizm jest jednym z komponentów współczesności. Choć to trudne, to jednak taki atak należy przyjąć ze spokojem i nie dać się sprowokować do konfliktu i brutalnej wymiany zdań. Gdyż kiedy zaczyna się konfrontacja, to kończy się ewangelizacja. W czasie kolędy należy odważnie i klarownie przedstawić zasady wiary i wymagania Kościoła, ale zawsze w ramach kulturalnej rozmowy ${ }^{21}$. Porażka w dyskusji nie koniecznie musi być przegraną nowej ewangelizacji, gdyż może być początkiem pozytywnej przemiany. Jest to szansa dla duszpasterza, ponieważ zostanie zmuszony do szukania nowych argumentów oraz jest to szansa dla osób dystansujących się od Kościoła, ponieważ oświeca światłem Bożej nauki ich sumienia i pobudza do myślenia.

\footnotetext{
${ }^{20}$ Zob. W. Ś m i g i e l: Uczestnictwo wiernych świeckich $w$ budowaniu Kościoła-Wspólnoty. Studium teologicznopastoralne w świetle nauczania Kościoła (1962-2009). Lublin 2010 s. 362.

${ }^{21}$ Zob. A. P o t o c k i: Odwiedziny kolędowe jako forma duszpasterstwa matżeństw niesakramentalnych i rozbitych. „Homo Dei”. R. 59: 1990 nr 3-4 s. 252-261.
} 


\section{Wnioski i propozycje pastoralne}

Podstawą relacji z osobami luźno związanymi z Kościołem jest szacunek dla ich postawy życiowej. Nie chodzi tutaj o fałszywą tolerancję, która zasadniczo oparta jest na relatywizmie, ale o założenie, że ów dystans do Kościoła ma jakieś przyczyny i uwarunkowania. Kościół szanuje takie samookreślenie się człowieka, które jest spowodowane osobistymi doświadczeniami lub wychowaniem wyniesionym $\mathrm{z}$ domu rodzinnego.

Pomocny w czasie kolędy jest dialog, który przecież uchodzi za narzędzie nowej ewangelizacji ${ }^{22}$. Powinien on odznaczać się życzliwością, jasnością, roztropnością i łagodnością, której Chrystus kazał uczyć się od siebie (zob. Mt 11,29). Zaprzeczeniem dialogu byłaby rozmowa odznaczająca się pychą, stosująca uszczypliwe słowa, złośliwe wyrażenia, boleśnie drażniące innych. Dialog czerpie swoją siłę z faktu, że głosi prawdę, rozsiewa dary miłości, niczego nie narzuca. Oprócz zaufania do mocy własnych słów, potrzebne jest w dialogu także zaufanie. Kto prowadzi rozmowę stara się poznać usposobienie słuchającego i w razie potrzeby coś zmienia u siebie lub w sposobie przedstawienia sprawy. W dialogu prowadzonym $\mathrm{w}$ taki sposób prawda łączy się z miłością, a zrozumienie z życzliwością (ES 81-82).

Dialog zakłada nie przekreślanie z góry dobrej woli człowieka dystansującego się od Kościoła. W takich przypadkach należy przede wszystkim pamiętać o zasadzie miłości bliźniego i szacunku dla jego poglądów (por. KDK 92). Tylko szukanie płaszczyzny zrozumienia, dialogu i poszukiwania prawdy, może doprowadzić do zbliżenia $\mathrm{z}$ Kościołem. Z ludźmi oddalonymi od Kościół też można budować pewną wspólnotę opartą na uniwersalnych wartościach, poszanowaniu prawdy, uznaniu piękna i pomnażaniu dobra.

Przydatne w czasie wizyty duszpasterskiej mogą okazać się przygotowane wcześniej pomoce. To może być folder z informacjami o parafii - podkreślający pozytywne działanie Kościoła w lokalnym środowisku; tekst wyznania wiary z krótkim objaśnieniem ${ }^{23}$; zaproszenie na niedzielną Eucharystię lub katechezę

\footnotetext{
${ }^{22}$ Pojęcie dialogu stosowane czasem zamiennie z colloquium stało się kluczowym w nauczaniu Soboru Watykańskiego II. Natomiast papież P a w e ł V I w swojej pierwszej encyklice Ecclesiam suam (06 VIII 1964) uczynił z tego pojęcia program działania dla Kościoła. Klerycy w ramach formacji seminaryjnej, a duchowni w czasie formacji permanentnej powinni być przygotowywani do prowadzenia dialogu wewnątrzkościelnego, a także do dialogu z dystansującymi się od Kościoła (por. PdV 70-81). W dobie postępujących procesów laicyzacyjnych postawa dialogiczna uzupełnia postawę apologetyczną.

${ }^{23} \mathrm{Z}$ okazji Roku Wiary niektóre diecezje i parafie w Polsce przygotowały pomoce duszpasterskie, które rozdawano wiernym w czasie wizyty duszpasterskiej np. Wierzę, Panie! Poznań. Kuria Metropolitarna 2012 (ss.32). Broszura zawiera wprowadzenie abp. S. Gą de ckiego, metropolity poznańskiego; wykład prawd wiary (czym jest wiara? wiara jest darem od Boga, wiara i rozum, wiara w Kościele); odpowiedź na pytania, trudności, wątpliwości i zarzuty (np. wszystko
} 
dorosłych; informacja o wspólnocie działającej na terenie parafii, a nakierowanej na dystansujących się od Kościoła (np. Droga Neokatechumenalna) lub prosty obrazek z modlitwą za tych, którzy dystansują się od Kościoła. Czasem skuteczne jest zaproszenie na konkretne wydarzenie ewangelizacyjne. Osoby luźno związane z Kościołem zasadniczo nie utrzymują kontaktu z parafią, a jeśli przyjmują duszpasterza, to jest to wydarzenie okazjonalne. Dlatego dobrze, jeśli duchowny poprosi o możliwość następnego spotkania, zaproponuje wypożyczenie literatury teologicznej lub przynajmniej zachęci do odwiedzania katolickich witryn w Internecie. Dobór odpowiednich środków i metod zależy w dużej mierze od uzdolnień i kwalifikacji duszpasterza oraz od pytań i zainteresowań przyjmujących kolędę.

Ciekawą propozycję pastoralną, którą można zaadoptować do naszych warunków, zaprezentowała Konferencja Episkopatu Włoch. Opublikowała ona List do poszukujących Boga ${ }^{24}$. We wstępie do tego dokumentu abp Bruno Forte napisał, że list jest zaadresowany do tych, którzy poszukują Boga oraz do tych, którzy nie poszukują, ale są zainteresowani kwestiami filozoficznymi. Może warto skorzystać $\mathrm{z}$ tego pomysłu i w ramach parafii napisać list do ludzi, którzy luźno są związani z Kościołem, wyjaśniając im podstawy wiary i zapraszając do wspólnoty wierzących. Kolęda byłaby okazją do rozmowy na tematy poruszone w liście.

Ważną, ale niezwykle delikatną sprawą są ofiary kolędowe. Zazwyczaj osoby luźno związane z Kościołem żadnych ofiar nie składają, co jest logiczną konsekwencją ich postawy życiowej. Jednak zdarzają się odstępstwa od tej zasady, a wówczas duchowni powinni przyjmować ofiary kolędowe $\mathrm{z}$ wielką roztropnością - nawet zakładając w punkcie wyjścia, że z takich ofiar należy zrezygnować. Łatwo bowiem można narazić się na zarzut, że kolęda jest przede wszystkim okazją do zbierania pieniędzy. Wierzący i praktykujący raczej dobrze orientują się $\mathrm{w}$ potrzebach parafii i rozumieją potrzebę i znaczenie dobrowolnych ofiar. Jednak osoby luźno związane z Kościołem nie posiadają doświadczenia wspólnoty, nie znają prawdziwego przeznaczenia datków, a ich wizerunek parafii jest ukształtowany przez plotki, skandale i obrazy medialne. Przyjęcie od nich ofiary może sprawić, że w ich oczach wysiłki ewangelizacyjne stracą na znaczeniu.

Wizyta duszpasterska, zwana kolędą, może być pozytywnym impulsem do rozpoczęcia długiego procesu pogłębienia wiary i powrotu do żywej wspólnoty Kościoła. Duszpasterz nie powinien mieć złudzeń, że w czasie kolędy całkowicie przekona rozmówcę i doprowadzi do jego nawrócenia.

jedno w co kto wierzy, najważniejsze jest być dobrym człowiekiem; nie wierzę w Kościół, wierzę w Chrystusa; moje dzieci przestały chodzić do kościoła itp.); wybór fragmentów Pisma Świętego traktujących o wierze; kompilację modlitw o wiarę oraz sześć prawd wiary.

${ }^{24}$ Conferenza Episcopale Italiana: Lettera ai cercatori di Dio. Milano 2009. 
Czasem wystarczy pełna kultury i życzliwości rozmowa, która pozostawi tak zwane dobre wrażenie i przełamie niechęć. Dobra Nowina ma tę zdolność, że raz zasiana już nie ginie, ale cierpliwie czeka na stosowne warunki do wzrostu. 